\title{
Trace element nutrition in the tropical zebu cattle type. Lessons from the Gilgel Gibe catchment, Ethiopia'
}

\author{
Veronique Dermauw \\ Clinical and Experimental Endocrinology, KULeuven, Belgium
}

\begin{abstract}
In the tropics, cattle are majorly dependent on natural pastures growing on poor soils and as a result prone to trace element deficiencies. This work investigated several aspects of trace element nutrition in zebu (Bos indicus) cattle, the most widely used cattle type in the tropics. Through several trials conducted at the Gilgel Gibe catchment, Ethiopia, we aimed to study factors influencing the flow of trace elements from soil to plant and grazing zebu cattle, and to investigate the impact of trace element status on health, production and trace elements in animal products. Overall, trace element, e.g., $\mathrm{Cu}$, deficiencies were widely prevalent. Environment and certain grazing strategies were intimately related and affected trace element supply whereas cattle type affected trace element status. The effect of trace element status on trace elements in animal products was obvious, whereas the impact on health and production was less clear-cut.
\end{abstract}

Key words: trace elements, minerals, cattle, zebu, Bos indicus, Ethiopia, tropics

\section{Introduction and objectives}

Throughout the animal kingdom, a certain dietary supply of trace elements (e.g. copper $(\mathrm{Cu})$, zinc $(\mathrm{Zn})$, selenium (Se)) is known to be essential for optimal health (Bender, 2007). In the early days of trace element research in farm animals, numerous studies confirmed their importance for cattle, as supplementation of these elements alleviated elusive symptoms (e.g. claw malformations, muscle skin lesions, diarrhoea) and improved production (McDowell \& Arthington, 2005). Following these trials, authors around the globe reported shortages in some trace elements as well as excess in others in natural pastures, indicating an omnipresent risk for trace element imbalance in grazing cattle (Abdelrahman et al., I998; Mortimer et al., I999; Govasmark et al., 2005a,b). Indeed, the 
grazing cow is part of the trace element flow from soil to plant and animal and back, and the bovine trace element status is directly influenced by this flow, although many indirect factors are yet to be unravelled (Suttle, 20I0). Furthermore, studies investigating the effects of trace element supply on body functions (e.g., immunity: Spears, 2000; Weiss \& Spears, 2006; Spears \& Weiss, 2008) as well as on production (Ward \& Spears, I997; Engle \& Spears, 2000) often produce conflicting results. Additionally, few studies investigated the impact of trace element supply under practical farming conditions (Wichtel, 2003). Finally, the influence of the established trace element status in the animal (e.g deficient, optimal, in excess) on trace element concentrations in edible tissues and milk, is not well understood (Garcia-Vaquero et al., 20II; Rey-Crespo et al., 20I3).

In tropical areas, poor grasslands remain the primary bottleneck for optimal cattle production (McDowell \& Arthington, 2005) and several environmental characteristics (e.g. parent material, heavy rainfall) increase the risk for trace element imbalances in cattle (Dudal, 1980). The zebu cattle type (Bos indicus), domesticated independently from the taurine type (Bos taurus), is spread around the globe with a predominant presence in these tropics, e. g. South Asia and large parts of Africa (MacHugh et al., I997; Bradley et al., I998; Hanotte et al., 2000). Zebu cattle, with the pronounced hump and cossum (Figure I), are renowned for their adaptive traits to a harsh environment, with a high tolerance towards heat stress, high disease burden and poor dietary quality (Turner, I980; Bradley et al., I998; Macedo et al., 2013). Few studies were, however, performed on trace elements in Bos indicus (-influenced) cattle. In Ethiopia, the world's fifth largest cattle holder (FAO, 2013), poor communal grass lands are often characterised by erosion and overgrazing (Devi et al., 2008). A coherent grazing management policy is absent and farmers have low financial resources to supplement zebu cattle with high quality grains or by-products, let alone trace element supplements. In this country, beef oriented zebu cattle dominate the cattle population, in addition to dairy oriented crossbreeds with taurine Holstein-Friesians (Bos indicus x Bos taurus), a mix of sanga and zenga cattle (Dadi et al., 2008) and the small indigenous taurine Sheko population $(\leq 4000$ individuals left according to Taye et al. (2009)).

This work aimed to obtain a broad insight in trace element nutrition in zebu cattle. Overall, our objectives were to: i) assess the trace element supply for zebu (-influenced) cattle, ii) evaluate the bovine trace element status, iii) define factors influencing the soilplant-animal flow (e.g., environment, management, plant and animal factors), iv) investigate the effect of bovine trace element status on different aspects of bovine health (e.g. anti-oxidant status, immunity) and production as well as on trace element storage in edible tissues and secretion in milk.

\section{Study area \& trial design}

The Gilgel Gibe catchment (Figure I), SW Ethiopia, was selected as our study site to investigate several aspects of trace element nutrition in the zebu cattle type. This catchment forms the main focus area of a multidisciplinary research project (IUC-JU programme of VLIR-UOS) investigating the impact of the local hydroelectric power plant 
with an adjacent reservoir and dam on human and animal health, ecology and agronomy, in order to improve the life quality of local communities. Here, farmers subside on mixed farming systems (Moti et al., 2012) and cattle are reported to be mainly of the indicine Guraghe-type (DAGRIS, 2007). Herds of such cattle are typically free-ranging on poor pastures. In and around Jimma, the largest city in the area, urban dairy farming is commonly practiced. Most cattle on these rather small farms are crosses of local zebu and Holstein Friesians. The animals are kept on a zerograzing regime with a cut-and-carry feeding system for forages, fed in combination with concentrates and by-products (Belay et al., 2012).

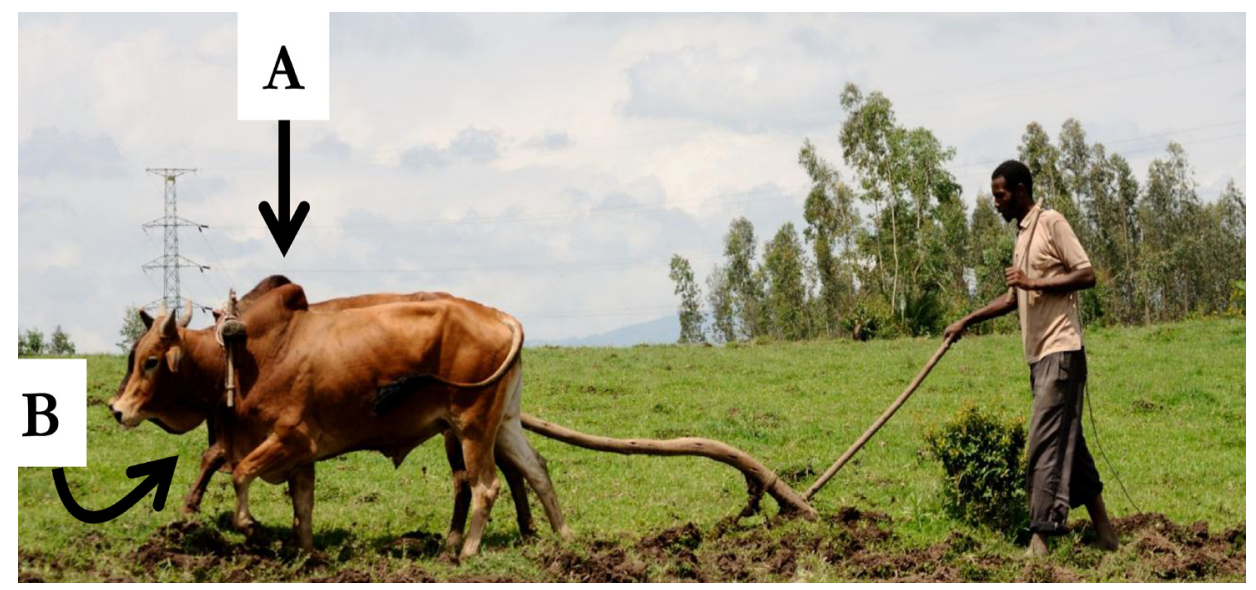

Figure 1. Zebu oxes ploughing the land at the Gilgel Gibe catchment, Ethiopia. $A=$ hump, $B=$ cossum.

The research was initiated with the investigation of the trace element content of consumed diets of grazing bovines and the effect of plant factors, environment and management on this content (Dermauw et al., 20I4d). Plants ingested by grazing herds of zebu cattle $(n=19)$ were sampled, total dietary intake was estimated through ten minute interval bite observation and other factors were monitored.

Afterwards, we aimed to evaluate the trace element status of grazing zebu cattle and to unravel associated factors. In two studies, individual plasma and pooled herd faeces were sampled in adult zebu cattle grazing at the catchment $(n=90)$ and liver in adult zebu bulls slaughtered at the local abattoir $(n=53)$ (Dermauw et al., 20I3a) and trace element concentrations in these samples were determined. Meanwhile, the impact of sex, age, body condition and the presence of parasitic infections was analysed.

We also considered the effective assessment of the status of the macromineral sulfur $(\mathrm{S})$, given the high prevalence of $\mathrm{Cu}$ deficiency in the tropics, and the role of $\mathrm{S}$ as a $\mathrm{Cu}$ antagonist. Evaluating the status of this element is thus important, yet remains difficult. Rumen fluid S concentrations are preferred, but are difficult to sample under practical conditions. Therefore, we aimed to evaluate salivary $S$ concentrations as estimators of $S$ 
status in cattle. Saliva and rumen fluid samples were collected from dairy cows ( $n=16$ ) with a rumen fistel as well as samples of different feedstuffs offered to the animals, and $\mathrm{N}$ and $\mathrm{S}$ concentrations were determined (Dermauw et al., 20I2).

In the next study, we aimed to identify the early effects of dietary trace elements on anti-oxidant status and production (Dermauw et al., 2013 b). To investigate this, adult grass-fed zebu bulls $(n=8)$ received either a control or additional trace element supplementation (zinc ( $\mathrm{Zn})$, manganese $(\mathrm{Mn}), \mathrm{Cu}$, Se, jodide (I) and cobalt (Co)) during four weeks while monitoring nutrient digestibility and trace element concentrations in plasma and faeces.

Subsequently, the effect of trace element supplementation under practical farming conditions on bovine trace element status and milk concentrations as well as antioxidant status, immune response and performance was investigated (Dermauw et al., 20I4c). In a double-blinded intervention study, small-scale urban dairy farms $(n=16)$ with crossbred (zebu x taurine) cows were enrolled in a trace element supplementation programme $(\mathrm{Cu}$, $\mathrm{Zn}, \mathrm{Se}$, Co and I) for I50 days.

Afterwards, we studied the trace element distribution in edible bovine tissues, as these are of importance both for animal health and human nutrition (Dermauw et al., 20I4a). At the local abattoir, adult zebu bulls were sampled for semitendinosus and cardiac muscle, liver and kidney $(n=60)$ and plasma $(n=28)$ in order to investigate trace element distribution and storage.

Finally, we aimed to investigate potential differences in trace element metabolism in zebu and crossbred cattle. Throughout an eleven week trial (Dermauw et al., 2014b), zebu and zebu x Holstein Friesian cross heifers $(n=16)$ were fed a Cu deficient grass-diet supplemented with the $\mathrm{Cu}$ antagonist molybdenum (Mo) and plasma and tissue trace element concentrations were monitored.

\section{Results \& Conclusions}

The trace element supply for zebu-influenced cattle in the Gilgel Gibe catchment, Ethiopia, was imbalanced (Dermauw et al., 20I3b, 2014b,c,d), based on the comparison of dietary trace element levels with reported requirements for cattle. However, the applicability of these reported Bos taurus requirements for zebu cattle was not investigated yet. Sampled forages contained low amounts of $\mathrm{Cu}$, probably aggravated by high levels of iron (Fe) and possibly Mo and S, known $\mathrm{Cu}$ antagonists. The trace elements Se and to a lesser degree, $\mathrm{Zn}$ were supplied in concentrations below requirements, especially for dairy cattle. Concentrations of other trace elements seemed sufficient for cattle. Soil type, elevation and plant group appeared to be the major determining factors for trace element supply (Dermauw et al., 20I4d). Environment and certain grazing strategies were intimately related, and might provide both explanation and solution for hampered trace element supply.

Concomitantly with the low dietary trace element supply found in the Gilgel Gibe catchment, low trace element concentrations were found in transport and storage pools of sampled zebu-influenced cattle in the region (Dermauw et al., 2013a, 20I4a,b,c). More 
specifically, $\mathrm{Cu}$ deficiency was observed in almost half of the sampled animals, based on status evaluation by means of plasma and liver samples (Figure 2). However, the value of Bos taurus threshold values necessary to assess trace element status has not been investigated yet for zebu-influenced cattle. Depending on thresholds from different authors, $\mathrm{Mn}$ and/or Se deficiency was present in cattle in the area. The status of other trace elements seemed adequate. Based on the tissue levels, Fe seemed the most important $\mathrm{Cu}$ antagonist for cattle in the region, which is in line with forage data. The status of another antagonist, $S$, remained difficult to determine, and saliva concentrations did not prove to be indicative of rumen fluid S concentrations (Dermauw et al., 2012). Linear regression analysis showed that for Co and Se, plasma samples could be useful for prediction of liver values (data: Dermauw et al., 20I4a, b). Using the dichotomized approach, plasma $\mathrm{Cu}$ concentrations proved to be very strong predictors of liver concentrations above or below cut-off point for deficiency (data: Dermauw et al., 20I4a, b). Factors related to a certain trace element status (data: Dermauw et al., 2013b, 20I4a,b,c) were age, sex, body condition score and type of cattle. More research is needed to fully unravel the extent of the impact of these factors, particularly in zebu cattle. Moreover, the potential difference in trace element metabolism between different types (Bos indicus vs. Bos indicus x Bos taurus) of cattle (Dermauw et al., 20I4b) requires extra attention, as it might have a large impact on the optimal nutritional management of these animals.

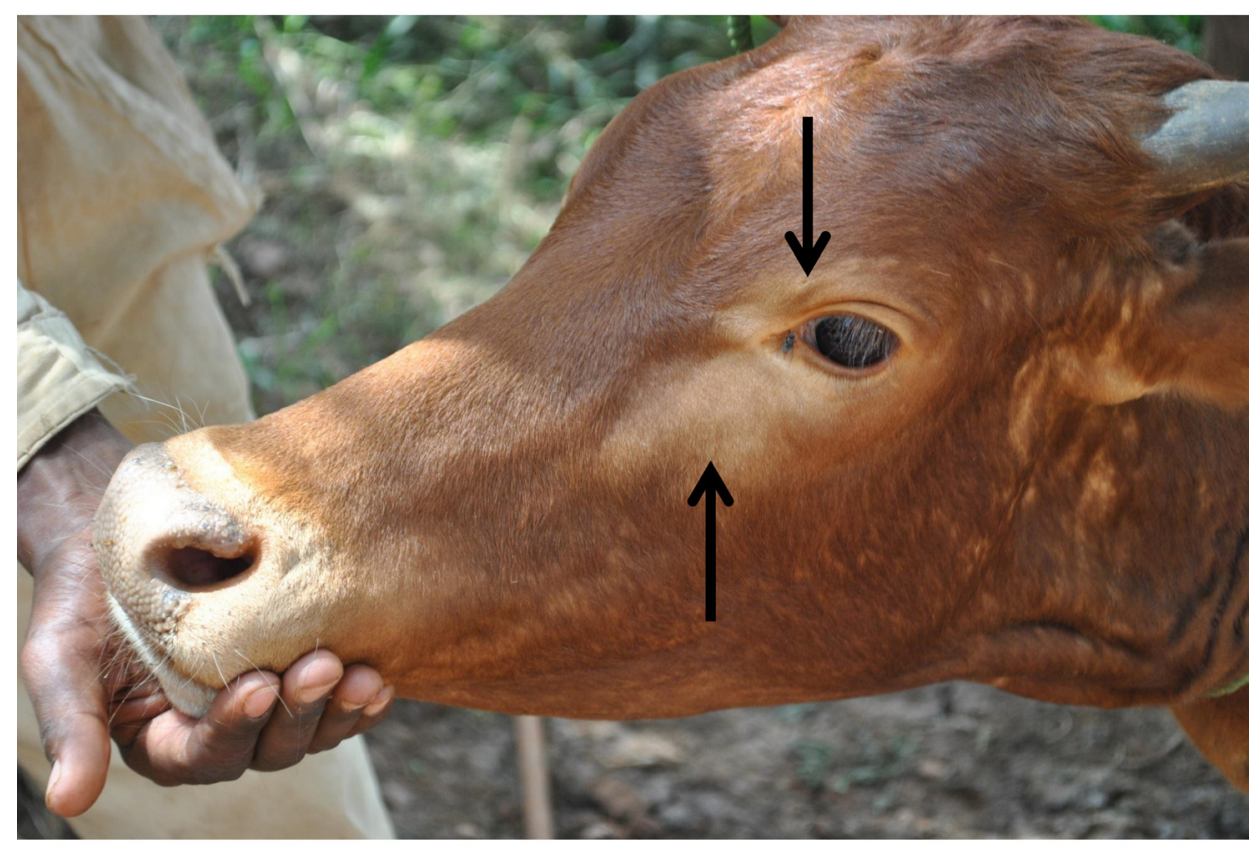

Figure 2. Close-up of a heifer exhibiting depigmentation of hairs around the eyes, a typical sign of Cu deficiency (called "copper glasses"). 
In zebu and crossbred cattle originating from the Gilgel Gibe catchment, Ethiopia, consuming diets low in trace elements and with an inadequate trace element status as a consequence, trace element supplementation raised trace element concentrations in the plasma transport pool (Dermauw et al., 2013b, 20I4c). Nonetheless, in the same cattle, we did not witness any beneficial effects of such trace element supplementation on anti-oxidant status, immunity and disease resistance or on production (Dermauw et al., 20I3b, 2014c). More specifically, trace element supplementation did not seem to increase levels of the antioxidant enzymes (Cp and SOD) in zebu cattle (Dermauw et al., $2013 \mathrm{~b}$ ), nor did it seem to increase measures of antioxidant power (FRAP) or decrease the amount of oxidative stress (TBARS) in crossbred cattle (Dermauw et al., 2014c). Likewise, no effect was observed on immune response (antibody titer upon vaccination) nor on disease resistance (degree of mastitis) in crossbred cattle (Dermauw et al., 20I4c). Finally, trace element supplementation did not seem to affect production, neither in the more beef orientated zebu cattle (Dermauw et al., 2013b) nor in the crossbred dairy cattle (Dermauw et al., 20I4c). Comparable studies in zebu cattle are largely absent. At the same time, other studies investigating almost all of the above mentioned subjects in Bos taurus cattle report contradicting results, probably partly because of the heterogeneity of experiments performed. In particular, studies investigating the effects of trace element supplementation under field conditions are essential to unravel the magnitude of trace element status impact on cattle performance and production.

In zebu and crossbreed cattle grazing at the Gilgel Gibe catchment, Ethiopia, low dietary supply of trace elements and low trace element status coincided with lowered trace element distribution and secretion (Dermauw et al., 20I4a,c). In zebu cattle, low concentrations of $\mathrm{Cu}$ and Se were observed in edible tissues (e.g., kidney, skeletal muscle, heart), whereas Fe levels were rather high, based upon comparison with reported ranges for Bos taurus cattle and other literature (Dermauw et al., 20I4a). Based on ranks, for most elements, kidney trace element concentrations were reasonably associated with trace element status. For concentrations in muscle (semitendinosus and cardiac muscle), this was less pronounced, but a strong association with status was observed for Co and Se (Dermauw et al., 20I4a). On average, the potential contribution of a portion (200 g) of kidney and liver to human trace element nutrition was large, whereas both muscle types were poor suppliers of trace elements for humans (data: Dermauw et al., 2014a). In crossbred dairy cattle, milk concentrations of $\mathrm{Cu}$ and Se were low and $\mathrm{Mn}$ concentrations high, but all were within reported normal ranges (Dermauw et al., 20I4c). Based on ranks, for most elements, a poor association was observed between milk trace element concentrations and trace element status, except for milk Se, which corresponded reasonably well with status (data: Dermauw et al., 20I4c). A glass of milk was a rather poor supplier of trace elements for human nutrition, except for Mo (data: Dermauw et al., 20I4c). More studies are needed to unravel the factors which contribute to any remaining variation in the association between trace element status and trace element distribution and secretion. 


\section{Acknowledgments}

This work was carried out within the context of $\mathrm{PhD}$ research, funded by an Agency for Innovation and Science (IWT Vlaanderen) scholarship (IWT SBogI348, 093348) and it participated in the Interuniversity Cooperation Programme with Jimma University (IUCJU) of the Flemish Interuniversity Council - University Developmental Cooperation (VLIRUOS). Sincere thanks to my supervisor prof. Geert Janssens, all contributing scientists and technical staff for their support and input.

\section{References}

Abdelrahman, M.M., Kincaid, R.L., \& Elzubeir, E.A. (1998). Mineral deficiencies in grazing dairy cattle in Kordofan and Darfur regions in Western Sudan. Tropical Animal Health and Production, 30, pp. I23-I35.

Belay, D., Yisehak, K., \& Janssens, G. (2012). Productive and reproductive performance of zebu X Holstein-Friesian crossbred dairy cows in Jimma town, Oromia, Ethiopia. Global Veterinaria, 8, pp. 6772.

Bender, D. (2007). Introduction to nutrition and metabolism (4th Edition.). CRC Press, Taylor \& Francis Group.

Bradley, D.G., Loftus, R.T., Cunningham, P., \& MacHugh, D.E. (1998). Genetics and domestic cattle origins. Evolutionary Anthropology, 6, pp. 79-86.

Dadi, H., Tibbo, M., Takahashi, Y., Nomura, K., Hanada, H., \& Amano, T. (2008). Microsatellite analysis reveals high genetic diversity but low genetic structure in Ethiopian indigenous cattle populations. Animal Genetics, 39, pp. 425-43I.

DAGRIS. (2007). Domestic Animal Genetic Resources Information System (DAGRIS). S. Kemp, Y. Mamo, B. Asrat, \& T. Dessie (Eds.). Addis Ababa, Ethiopia: International Livestock Research Institute. http://dagris.ilri.cgiar.org.

Dermauw, V., Froidmont, E., Dijkstra, J., De Boever, J., Vyverman, W., Debeer, A.-E., Janssens, G.P.J. (2012). Sulphur levels in saliva as an estimation of sulphur status in cattle: a validation study. Archives of Animal Nutrition, 66, pp. 507-513.

Dermauw, V., Yisehak, K., Belay, D., Van Hecke, T., Du Laing, G., Duchateau, L., Janssens, G.P.J. (2013a). Mineral deficiency status of ranging zebu (Bos indicus) cattle around the Gilgel Gibe catchment, Ethiopia. Tropical Animal Health and Production, 45, pp. II39-II47.

Dermauw, V., Yisehak, K., Dierenfeld, E., Du Laing, Buyse, J., Wuyts, B., Janssens, G.P.J. (2013b). Effects of trace element supplementation on apparent nutrient digestibility and utilisation in grass-fed zebu (Bos indicus) cattle. Livestock Science, I55, pp. 255-26r.

Dermauw, V., Lopez-Alonso, M., Duchateau, L., Du Laing, G., Tolosa, T., Dierenfeld, E., Clauss, M., Janssens, G. P. J. (20I4a). Trace element distribution in selected edible tissues of zebu (Bos indicus) cattle slaughtered at Jimma, SW Ethiopia. PLoS One 9, e85300.

Dermauw, V., De Cuyper, A., Duchateau, L., Waseyehon, A., Dierenfeld, E., Clauss, M., Peters, I.R., Du Laing, G., Janssens, G.P.J. (20I4b). Trace element metabolism in zebu (Bos indicus) and crossbreed (Bos indicus $x$ Bos taurus) cattle fed a Cu deficient diet. Journal of Animal Science (accepted for publication).

Dermauw, V., Du Laing, G., Buyse, J., Brochier, B., Van Gucht, S., Duchateau, L., Janssens, G.P.J. (2014c). Impact of $a$ trace element supplementation programme on health and performance of tropical crossbreed (Bos indicus $x$ Bos taurus) dairy cattle: a double-blinded randomized field trial. Journal of Animal Nutrition and Animal Physiology (accepted for publication).

Dermauw, V., Van Hecke, T., Yisehak, K., Du Laing, G., Van Ranst, E., Duchateau, L., Janssens, G.P.J. (2014d). Ingested plant species, environmental factors and grazing management affect estimated dietary trace element concentrations in grazing zebu (Bos indicus) cattle. (in preparation). 
Devi, R., Tesfahune, E., Legesse, W., Deboch, B., \& Beyene, A. (2008). Assessment of siltation and nutrient enrichment of Gilgel Gibe dam, Southwest Ethiopia. Bioresource Technology, 99, pp. 975979 .

Dudal, R. (I980). Soil-related constraints to agricultural development in the tropics. In: Priorities for Alleviationg SoilRelated Constraints to Food Production in the Tropics. Laguna, Philippines: International Rice Research Institute.

Engle, T., \& Spears, J. (2000). Effects of dietary copper concentration and source on performance and copper status of growing and finishing steers. Journal of Animal Science, 78, pp. 2446-245I.

FAO (2013). FAOSTAT. Retrieved from http://faostat3.fao.org (Accessed on 26-08-2013).

Garcia-Vaquero, M., Miranda, M., Benedito, J.L., Blanco-Penedo, I., \& Lopez-Alonso, M. (20II). Effect of type of muscle and $\mathrm{Cu}$ supplementation on trace element concentrations in cattle meat. Food and Chemical Toxicology, 49, pp. I443-I449.

Govasmark, E., Steen, A., Bakken, A.K., Strom, T., Hansen, S., \& Bernhoft, A. (2005a). Copper, molybdenum and cobalt in herbage and ruminants from organic farms in Norway. Acta Agriculturae Scandinavica, Section A, 55, pp. 2I-30.

Govasmark, E., Steen, A., Bakken, A. K., Strom, T., \& Hansen, S. (2005b). Factors affecting the concentration of $\mathrm{Zn}, \mathrm{Fe}$ and $\mathrm{Mn}$ in herbage from organic farms and in relation to dietary requirements of ruminants. Acta Agriculturae Scandinavica, Section B, 55, pp. I3I-I42.

Hanotte, O., Tawah, C.L., Bradley, D.G., Okomo, M., Verjee, Y., Ochieng, J., \& Rege, J.E. (2000). Geographic distribution and frequency of a taurine Bos taurus and an indicine Bos indicus $\mathrm{Y}$ specific allele amongst sub-saharan African cattle breeds. Molecular Ecology, 9, pp. 387-396.

Macedo, A., Costa, E., Silva, A., Paixao, T., \& Santos, R. (2013). Monocyte-derived macrophages from Zebu (Bos taurus indicus) are more efficient to control Brucella abortus intracellular survival than macrophages from European cattle (Bos taurus taurus). Veterinary Immunology and Immunopathology, I5I, pp. 294-302.

MacHugh, D., Shriver, M., Loftus, R., Cunningham, P., \& Bradley, D. (I997). Microsatellite DNA variation and the evolution, domestication and phylogeography of taurine and zebu cattle (Bos taurus and Bos indicus). Genetics, I46, pp. I07I-1086.

McDowell, L.R., \& Arthington, J.D. (2005). Minerals for Grazing Ruminants in Tropical Regions. (4th ed.). Gainesville, FL, USA: University of Florida, IFAS.

Mortimer, R. G., Dargatz, D.A., \& Corah, L.R. (1999). Forage analyses from cow/calf herds in 23 states. Fort Collins, Colorado, USA: USDA, APHIS:VS, Centers for Epidemiology and Animal Health.

Moti, Y., Fikru, R., Van Den Abbeele, J., Buscher, P., Van den Bossche, P., Duchateau, L., \& Delespaux, V. (2012). Ghibe river basin in Ethiopia: present situation of trypanocidal drug resistance in Trypanosoma congolense using tests in mice and PCR-RFLP. Veterinary Parasitology, I89, pp. 197-203.

Rey-Crespo, F., Miranda, M., \& Lopez-Alonso, M. (2013). Essential trace and toxic element concentrations in organic and conventional milk in NW Spain. Food and Chemical Toxicology, 55, pp. 513-518.

Spears, J.W. (2000). Micronutrients and immune function in cattle. Proceedings of the Nutrition Society, 59, pp. 587-594.

Spears, J.W, \& Weiss, W.P. (2008). Role of antioxidants and trace elements in health and immunity of transition dairy cows. The Veterinary Journal, I76, pp. 70-76.

Suttle, N. (2010). Mineral Nutrition of Livestock (4th ed.). Wallingford, Oxfordshire: CABI Publishing.

Taye, T., Ayalew, W., \& Hegde, B. (2009). Status of Ethiopian indigenous Sheko cattle breed and the need for participatory breed management plan. Ethiopian Journal of Animal Production, 9, pp. I-I2.

Turner, J. (1980). Genetic and biological aspects of zebu adaptability. Journal of Animal Science, 50, pp. I2OI-I205.

Van Ranst, E., Dumon, M., Tolossa, A., Cornelis, J.-T., Stoops, G., Vandenberghe, R., \& Deckers, J. (20II). Revisiting ferrolysis processes in the formation of Planosols for rationalizing the soils with stagnic properties in WRB. Geoderma, I63, pp. 265-274. 
Ward, J., \& Spears, J. (1997). Long-term effects of consumption of low-copper diets with or without supplemental molybdenum on copper status, performance, and carcass characteristics of cattle. Journal of Animal Science, 75, pp. 3057-3065.

Weiss, W.P., \& Spears, J.W. (2006). Vitamin and trace mineral effects on immune function of ruminants. In K. Sejrsen, T. Hvelplund, \& M.O. Nielsen (Eds.), Ruminant Physiology, Utrecht, The Netherlands: Wageningen Academic Publishers, pp. 473-496.

Wichtel, J.J. (2003). Micronutrient research: why a cow is not a large rat. The Veterinary Journal, I66, pp. 107-108. 